\title{
15
}

\section{Measuring social distances with shared Lapita motifs: Current results and challenges}

\author{
Scarlett Chiu
}

\begin{abstract}
This chapter illustrates the degree of motif similarity between 50 Lapita sites, in an attempt to measure whether social connections may be traced through the distribution of the same motifs. Data generated from 10 major motif themes identified from the Lapita Pottery Online Database are also presented, to strengthen further the hypothesis that a number of motif themes (a given motif and its alloforms) may serve the purpose of being house- or group-specific identity symbols. Current research suggests that the preference to create many regional-specific motifs while continuing to use some shared motifs is a common cultural phenomenon. In a linear diffusion model, the number of shared motifs employed by potters of all regions shows a sharp decline from west to east, with only a small number of motifs continuing to be reproduced as Lapita communities expanded further into Remote Oceania. It also shows that in most cases roughly half of the 'traditionally shared motifs' would be passed on to the neighbouring region located to the east of the previous one. Future examination of these motif themes, such as their temporal and spatial distribution patterns, and the motif construction rules applied by different groups to create alloforms of a certain motif theme, should contribute fruitfully to our understanding of the decorative traditions of the Lapita Cultural Complex.
\end{abstract}

\section{Introduction}

First recognised by the high degree of stylistic similarity of decorative techniques and motifs present among pottery assemblages (Golson 1961:176), the 'Lapita Cultural Complex' (Green 1979:34) has been regarded for a long time as a widespread early archaeological cultural entity that ranged from the Bismarck Archipelago of Papua New Guinea all the way to Samoa. Its distinctive pottery decoration style, especially the elaborate dentate-stamped motifs, is considered a central aspect of this cultural complex, alongside further traits such as other forms of artefacts, settlement patterns, subsistence practices and exchange networks, etc. (Kirch 1997:8-14). After decades of research, Lapita pottery with its distinctive decorative style is now conceived as 'one marker of a series of node and network type migrations that took place in Near Oceania and then Remote Oceania' that signals 'an outcome of intrusions by tiny populations carrying with them common cultural, biological and linguistic components' (Green 2003:112). Several regional pottery traditions, classified into a series of 'Lapita Provinces', developed out of this early and 
widespread pottery style, arguably as a result of a decreased frequency of interaction among regions (Green 1979:44; Kirch 1997:70). While the non-dentate-decorated and plainware pottery types, as well as the non-ceramic artefact assemblages and other components of this cultural complex, show a large degree of continuity, the dentate-stamped motifs and associated vessels dropped out of the archaeological record rather quickly, although in some regions they may have lasted longer than others (Green 2003).

In order to address issues concerning how new materialised symbols came into being, how such symbols acted in situations where heterogeneous groups might have interacted, and how they eventually became integrated into newly developed social networks that sometimes overlapped with each other over time and space, I have hypothesised the following in previous papers. First, as the knowledge and skills of making pottery are highly likely to be passed down from one generation to another at a house or village level, local potters might have formed a 'community of practice' (Lave and Wenger 1991). This would have provided a chance for various relationships to be developed among potters and raw material providers, thus facilitating the development of group-specific values with regards to vessel forms and motifs, and perhaps also with the regulation of end-product distribution ranges (e.g. Rossitto 1995:38-39). It is within this 'situated learning' (Lave and Wenger 1991) process that new members with a different background may be integrated into the local community (Chiu 2007, 2015).

Second, by controlling the rights to use, reproduce and modify existing house- or group-specific motifs and vessel forms, a local group may employ these symbols to differentiate themselves from outsiders, to associate themselves with relatives and friends over a vast region, and to generate status differences both within the group and perhaps even among related groups through display and exchange of valued items or titles (see Chiu 2003, 2005 for more discussion). An object that represents the house or a social group accumulates social value through its history of connections to various famous people who had previously possessed it and had the ability to give it out and later 'attract' it back to their house or group. The longer the object was circulated among famous people, the higher value and fame an object would possess. The ability to keep using these valued items/symbols while making them known to one's exchange partners inevitably increases the power and fame of the persons who are capable of conducting such a long-term plan, and thus contributes to the establishment of higher social rank (Weiner 1992:64-65).

Third, based on data that were available at the time of publication, it was hypothesised that motifs are not all created to serve the same purposes. Certain motif themes are more likely to be applied as central band decoration, while others are usually employed as zone markers or merely space fillers. Some may have served as house- or group-specific identity symbols, some as group or individual trade markers, and some as newly created aesthetic expressions to be associated with other motifs (Chiu 2015:200). Over time, some zone markers accumulated social value by being associated with the original socially charged central motif themes and transitioned into becoming central themes in their own right (Mead 1975:21).

In this chapter, the degree of motif similarity will be illustrated by various statistical means, in an attempt to see if one can trace various social connections through the use of the same motifs. It will also provide data generated from 10 major motif themes identified from the Lapita Pottery Online Database (LPOD, lapita.rchss.sinica.edu.tw/web/), to strengthen further the hypothesis that a number of differing motifs, not only face motifs, may serve the purpose of being a houseor group-specific identity symbol. 


\section{Data employed in this study}

The data employed in this study were generated via the LPOD; in total 2709 reconstructed motifs from 50 Lapita sites (see Table 15.1) were selected for this study, while another 2190 fragmented motifs were omitted. All motifs in the LPOD are recorded in the following manner: first, one must determine how many decorative regions and sections are present on the surface of a given potsherd. Standardised divisions of different regions for each of the known vessel forms have been published in the LPOD, in order to limit possible confusion while recording the location of a motif. A decorative 'Region' means the horizontal space usually marked by zone markers on the surface of a pot, and a 'Section' deals with the vertical or triangular spaces within a single horizontal band, usually marked by a significant change of the central motif, and also by zone markers or even appliqués. Second, motifs within each of the regions and sections of a region are input into the LPOD. New motifs are then drawn and assigned a new motif number, and up to 26 motif attributes, such as types of design elements, rules of the arrangement of design units, etc., are identified and recorded in the definition tables.

Due to Mead's argument that not only the way a single motif is constructed but also the way motifs are organised on the surface of a pot will reflect regional preferences of the Lapita potters (Mead 1975), it was decided to record motifs according to the direction of the major design elements that composed them. Since it is much easier to lump data together than split them into smaller units in a database, attributes such as motif orientation and the appearance of additional simple zone markers, etc., have affected the way a motif is registered. For example, a motif with a linked zone maker on its top will be recorded as a different motif to one that is exactly the same but with a zone marker linked to the bottom of the motif. By doing so, the number of new motifs inevitably increases. The advantage of recording motifs this way is to provide researchers with a finer degree of control over the real pattern of motif arrangement on the surface of a pot, and to search further for linked motifs across multiple regions, instead of single motif occurrence, to address issues concerning underlying grammars. Not only the occurrence of a single symbol, but also its association with other symbols may contribute greatly to our understanding of the meanings of Lapita motifs.

Time was also spent comparing all published motifs that were available, by comparing linedrawing of motifs to the original photos of a given sherd whenever such information is available. Overlapping motifs from various publications for the past 40 years have been cleared up, by deleting or reassigning motif numbers if they overlapped with older ones, in order to make sure that all individual motifs are recorded correctly in the database. However, there is no way to verify how others have recorded the motifs of an entire assemblage and/or whether they recorded motifs the way I do. Therefore, the data used in this chapter are generated from various tables and appendixes showing frequency or percentage of motifs identified by these authors (see Table 15.1). Previously known complex central motifs suggested by Spriggs (1990) and Sand $(1995,2007 b)$ form the foundation of the motif themes selected in this paper. The examination of motif construction rules allows the identification of new themes. So far more than 56 motif themes have been identified; however, in order to allow comparison among regions, this chapter only utilises the 10 most popular themes to illustrate how one can investigate this subject more deeply.

Since the current motif data have been recorded from both full pottery assemblages and from assemblages represented by incomplete published records, it is necessary to utilise presence and absence data in the following statistical analysis, in order to minimise the sample size effect. However, much larger assemblages from sites such as Lapita (13A), Talepakemalai (ECA), Etakosarai (ECB), Etapakengaroasa (EHB), Epakapaka rock shelter (EKQ) and Nenumbo (RF2) not only contribute greatly to the number of new motifs in the motif inventory, but also have

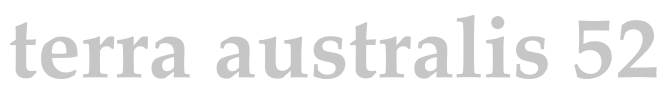


a large number of unique motifs that will inevitably influence the statistical results presented here. Nevertheless, patterns generated here will provide a useful starting point for testing various hypotheses about how social groups related to one another. No detailed chronological information is available at this stage to seriate all of these motifs. This information will be added into the LPOD once the updated information becomes available.

Table 15.1. Fifty Lapita pottery assemblages included in this study, and references recorded in the LPOD.

\begin{tabular}{|c|c|c|}
\hline \multirow{14}{*}{$\begin{array}{l}\text { The Bismarck } \\
\text { Archipelago (BKA) } \\
14 \text { sites }\end{array}$} & $\begin{array}{l}\text { Watom: Maravot, Vunavaung, Kainapirina, } \\
\text { Meyer Collections, Gallasch Collection }\end{array}$ & Anson 1983, 2000; Spriggs 1990 \\
\hline & Malekolon Plantation & Anson 1983; Summerhayes 2000 \\
\hline & Talasea & Anson 1983 \\
\hline & Talepakemalai (ECA) & $\begin{array}{l}\text { Anson 1983; Kirch 1988, 2000; Sand 2007a; motifs } \\
\text { recorded from actual pottery assemblage }\end{array}$ \\
\hline & Etakosarai (ECB) & Motifs recorded from actual pottery assemblage \\
\hline & Etapakengaroasa (EHB) & Motifs recorded from actual pottery assemblage \\
\hline & Epakapaka (EKQ) & Motifs recorded from actual pottery assemblage \\
\hline & Lamau & Gorecki et al. 1991 \\
\hline & Kreslo & Sand 2010; Summerhayes 2000 \\
\hline & Garua Island & Summerhayes 2000 \\
\hline & Apalo & Summerhayes 2000 \\
\hline & Paligmete & Summerhayes 2000 \\
\hline & Makekur & Phelan 1997; Summerhayes 2000 \\
\hline & Kamgot & Motifs recorded from actual pottery assemblage \\
\hline \multirow{4}{*}{$\begin{array}{l}\text { NW Solomons } \\
\text { (NW-SI) } 4 \text { sites }\end{array}$} & Kessa Plantation & Wickler 2001 \\
\hline & Tarmon & Wickler 2001 \\
\hline & West Sohano Island & Wickler 2001 \\
\hline & Honiavasa & Sand 2010 \\
\hline \multirow{5}{*}{$\begin{array}{l}\text { Solomon Islands } \\
\text { (R-SC) } \\
5 \text { sites }\end{array}$} & Nenumbo (RL2) & Anson 1983; Donovan 1973; Green 1976 \\
\hline & Nanggu (SZ8) & Anson 1983; Donovan 1973; Green 1976 \\
\hline & Ngamanie (RL6) & Anson 1983; Donovan 1973; Green 1976 \\
\hline & Bianga Mepala (SZ45) & Anson 1983 \\
\hline & Mdailu & Doherty 2009 \\
\hline \multirow{5}{*}{$\begin{array}{l}\text { Vanuatu (VU) } \\
5 \text { sites }\end{array}$} & Malo & Anson 1983; Hedrick n.d. \\
\hline & Makué & Galipaud 2010 \\
\hline & Teouma & $\begin{array}{l}\text { Bedford and Galipaud 2010; Bedford et al. 2010; } \\
\text { Bedford et al. 2007; Bedford and Spriggs } 2007\end{array}$ \\
\hline & Vao & Bedford 2006 \\
\hline & Uripiv & Sand 2010 \\
\hline \multirow{9}{*}{$\begin{array}{l}\text { New Caledonia } \\
\text { (NC) } \\
9 \text { sites }\end{array}$} & Vatcha & Anson 1983; Sand 1996; Spriggs 1990 \\
\hline & Lapita 13A & $\begin{array}{l}\text { Anson 1983; Gifford and Shutler 1956; Spriggs 1990; } \\
\text { Sand } 1996\end{array}$ \\
\hline & Koumac & Sand 1996 \\
\hline & Nessadiou & Sand 1996 \\
\hline & Kurin & Sand 2007b; Sand et al. 2002 \\
\hline & Patho & Sand 1996 \\
\hline & Naia & Sand 1996 \\
\hline & Vavouto & Motifs recorded from actual pottery assemblage \\
\hline & Goro & Motifs recorded from actual pottery assemblage \\
\hline
\end{tabular}




\begin{tabular}{|l|l|l|}
\hline \multirow{3}{*}{$\begin{array}{l}\text { Fiji (FJ) } \\
\text { 6 sites }\end{array}$} & Yanuca & Best 1984; Mead et al. 1975; Anson 1983 \\
\cline { 2 - 3 } & Natunuku & Anson 1983; Best 1984; Mead et al. 1975; Sand 2007a \\
\cline { 2 - 3 } & Naigani & Best 1984; Kay 1984 \\
\cline { 2 - 3 } & Lakeba & Best 1984 \\
\cline { 2 - 3 } & Bourewa & Clark 2010 \\
\cline { 2 - 3 } & Sigatoka & Birks 1973; Burley and Connaughton 2010 \\
\hline \multirow{5}{*}{$\begin{array}{l}\text { Tonga (T0) } \\
\text { sites }\end{array}$} & Nukuleka & Poulsen 1987 \\
\cline { 2 - 3 } & Ha'ateiho (To.3) & Poulsen 1987 \\
\cline { 2 - 3 } & Ha'ateiho (T0.4) & Poulsen 1987 \\
\cline { 2 - 3 } & Veitongo & Poulsen 1987 \\
\cline { 2 - 3 } & Tufu Mahina & Poulsen 1987 \\
\cline { 2 - 3 } & Lolokoka & Kirch 1988 \\
\hline \multirow{3}{*}{$\begin{array}{l}\text { Samoa (SA) } \\
\text { site }\end{array}$} & Mulifanua & Best 1984 \\
\hline
\end{tabular}

Source: Author's summary; see also references in table.

\section{Preliminary results}

Out of the 2709 reconstructed motifs, 1846 of them only appeared once among the 50 sites studied, 418 are shared by only two Lapita sites, 146 are shared by three Lapita sites, and 79 are shared by four sites. There are only 39 motifs that appear at 10 or more sites (Chiu 2015:188-190).

Table 15.2. Summary of motifs present in each region.

\begin{tabular}{|c|c|c|c|c|c|c|c|c|}
\hline & BKA (PNG) & NW-SI & $R / S C$ & VU & NC & F) & TO & SA \\
\hline BKA (PNG) & $\begin{array}{r}1316 \\
{[1040]}\end{array}$ & 31 & 137 & 81 & 190 & 74 & 46 & 1 \\
\hline NW-SI & 31 & $\begin{array}{l}52 \\
{[5]}\end{array}$ & 44 & 17 & 28 & 21 & 11 & 0 \\
\hline $\mathrm{R} / \mathrm{SC}$ & 137 & 44 & $\begin{array}{r}418 \\
{[226]}\end{array}$ & 59 & 107 & 50 & 25 & 0 \\
\hline VU & 81 & 17 & 59 & $\begin{array}{r}251 \\
{[141]}\end{array}$ & 68 & 45 & 24 & 0 \\
\hline NC & 190 & 28 & 107 & 68 & $\begin{array}{r}890 \\
{[657]}\end{array}$ & 73 & 40 & 1 \\
\hline FJ & 74 & 21 & 50 & 45 & 73 & $\begin{array}{r}265 \\
{[134]}\end{array}$ & 46 & 2 \\
\hline TO & 46 & 11 & 25 & 24 & 40 & 46 & $\begin{array}{r}181 \\
{[106]}\end{array}$ & 2 \\
\hline SA & 1 & 0 & 0 & 0 & 1 & 2 & 2 & $\begin{array}{r}2 \\
{[0]}\end{array}$ \\
\hline
\end{tabular}

The first number in the grey cells represents the total number of different motifs found in that particular region, while the number present in square brackets [ ] indicates the number of unique motifs of that region. Numbers in other cells represent the number of shared motifs between two regions.

Source: Author's summary.

An interesting pattern starts to emerge once motifs from each region have been calculated (see Table 15.2). Lapita sites located in the Bismarck Archipelago (BKA) have the highest number of motifs with a total of 1316, of which 1040 (79 per cent) are unique to this island group (the majority of which were found in the Mussau assemblages). Sites located in the northwest Solomon Islands Chain (NW-SI) have 52 motifs, of which five (9.6 per cent) are unique to 
this island group. Sites located at the Reefs-Santa Cruz Islands (R-SC) have 418 motifs, of which 226 (54.67 per cent) can only be found here. Vanuatu (VU) has 251 motifs, 141 (56.18 per cent) of which are unique. New Caledonia (NC) has 890 motifs, 657 (73.82 per cent) of which are unique. Fiji (FJ) has 265 motifs, 134 (50.57 per cent) of which are unique. Finally, Tonga (TO) has 181 motifs, 106 (58.56 per cent) of which are unique. There are only two motifs recorded so far in the LPOD for Samoa (SA), none of which are unique to this island group. Therefore, except for Samoa, and sites located in the north-west Solomon Island Chain that are arguably all dated to late in the Lapita period, roughly 50-60 per cent of the motifs identified are not being shared outside of regions listed above. The highest number of unique motifs comes from assemblages from the Bismarck Archipelago and New Caledonia, with both reaching over 70 per cent; no doubt the large sample sizes of these two sites have affected the outcome observed here. The high percentage of unique motifs found in most of these regions indicates that the preference was to create and generate regional-specific motifs while continuing to use some shared motifs.

The apparent emphasis on diversity within these assemblages can also be demonstrated by comparing the number of motifs shared between these regions (see Table 15.2). From the 1316 motifs that the Bismarck Archipelago has, 276 of them also appear in other regions. Out of these 276 motifs, only 31 (11.23 per cent) of them are shared with the north-west Solomon Islands Chain. The number changes to 137 (49.64 per cent) motifs shared with the Reefs-Santa Cruz Islands, and 81 (29.35) motifs shared with Vanuatu. When moving further into the Pacific we can see that the Bismarck Archipelago directly shares 190 (68.84 per cent) with New Caledonia, 74 (26.81 per cent) with Fiji, 46 (16.67) with Tonga, and only one (0.4) with Samoa. In most cases the greater the geographical distance between the two regions, the smaller the number of motifs shared. There are two exceptions to this rule: the first is the case between the Bismarck Archipelago and the north-west Solomon Islands Chain, which shares rather a low number of motifs, while a much higher number of motifs are shared between the north-west Solomon Islands Chain and the Reefs-Santa Cruz Islands. This pattern indicates there is a stronger relationship between these two regions, as Sheppard has stated (Sheppard 2011), and such motif sharing did not reach back to the Bismarck Archipelago during the later Lapita era. The second exception is between the Bismarck Archipelago and New Caledonia, which shares the highest number of motifs. At this stage, it is not quite clear what factors other than the sample size issue mentioned above may have contributed to this observed pattern.

Table 15.3. Number of motifs being shared continuously from west to east.

\begin{tabular}{|l|l|l|l|l|l|l|l|l|}
\hline & BKA (PNG) & NW-SI & R-SC & VU & NC & FI & T0 & SA \\
\hline BKA (PNG) & 1316 & 31 & 28 & 14 & 13 & 12 & 6 & 0 \\
\hline NW-SI & 31 & 52 & 44 & 15 & 13 & 12 & 6 & 0 \\
\hline R-SC & 28 & 44 & 418 & 59 & 41 & 21 & 9 & 0 \\
\hline VU & 14 & 15 & 59 & 251 & 68 & 30 & 11 & 0 \\
\hline NC & 13 & 13 & 41 & 68 & 890 & 73 & 22 & 1 \\
\hline FJ & 12 & 12 & 21 & 30 & 73 & 265 & 46 & 2 \\
\hline T0 & 6 & 6 & 9 & 11 & 22 & 46 & 181 & 2 \\
\hline SA & 0 & 0 & 0 & 0 & 1 & 2 & 2 & 2 \\
\hline
\end{tabular}

Bismarck Archipelago, north-west Solomon Islands Chain, Reefs-Santa Cruz, and Vanuatu all share the same 13 motifs (A2, A231, A35, A37, A421, A435, A436, A44, A442, A444, A448, A497 and A73) with New Caledonia. A73 got lost when moving out to Fiji from this list of 13 motifs, and only 6 of them (A37, A436, A442, A444, A448 and A497) lasted to Tonga.

Source: Author's summary. 
If one hypothesises that motifs are diffused from a central place located in the Bismarck Archipelago out to other regions in a standard wave-of-advance model, instead of the leapfrog model proposed by Sheppard (2011), then the following data indicate that motif similarity declined sharply as populations continued to advance out of the Bismarck Archipelago (see Table 15.3). Out of the 31 motifs that are shared between the Bismarck Archipelago and the north-west Solomon Islands Chain, only 28 can also be found in the Reefs-Santa Cruz Islands, and the number drops to 14 motifs shared with Vanuatu. From this group of 14 motifs, 13 also appear in New Caledonia, 12 of them reached Fiji, while only six motifs are shared from the Bismarck Archipelago all the way to Tonga. In other words, the Bismarck Archipelago, the Solomon Islands, the Reefs-Santa Cruz Islands and Vanuatu all share the same 13 motifs (A2, A231, A35, A37, A421, A435, A436, A44, A442, A444, A448, A 497 and A73) with New Caledonia. Motif A73 got lost from this list of 13 motifs when moving out to Fiji, and only six of them (A37, A436, A442, A444, A448 and A497) lasted to Tonga. These six motifs may be viewed as more popular or general motifs that might be used by any community. Such a list is entirely different from that which Green had summarised based on 14 Lapita assemblages (Green 1979: Figure 2.11).

If one skips data from the north-west Solomon Islands Chain based on the fact that these assemblages are dated to a later period, then the data look rather different. The current data show that out of the 276 motifs of the Bismarck Archipelago, 137 (49.63 per cent) of them appear in the Reefs-Santa Cruz Islands, and 49 (17.75 per cent of the original 276 motifs, 35.77 per cent of what had appeared in the Reefs-Santa Cruz Islands) of them appear in Vanuatu, 40 (14.49 per cent of the original 276 motifs, 81.63 per cent of what had appeared in Vanuatu) in New Caledonia, 21 (7.6 per cent of the original 276 motifs, 52.5 per cent of what had appeared in New Caledonia) in Fiji, and 9 (3.26 per cent of the original 276 motifs, 42.86 per cent of what had appeared at Fiji) in Tonga. None of these rather widely shared motifs reached Samoa, although this is likely to be heavily influenced by sample size. If one takes into account that Lapita communities of Fiji were more likely to be settled by groups coming in from Vanuatu, then out of the 49 shared motifs that appear in Vanuatu, 22 (44.5 per cent) of them show up in Fiji, and 10 (45.5 per cent) of them in Tonga.

In such a linear diffusion model, the number of shared motifs employed by potters of all regions still shows a sharp decline from west to east, and also that only a small number of motifs continued to be reproduced as Lapita communities expanded further into Remote Oceania. It also shows that in most cases, roughly half of the 'traditionally shared motifs' would be passed on to the neighbouring region located to the east of the previous one. One exception is from the Reefs-Santa Cruz Islands to Vanuatu, where only 36 per cent of the motifs were shared. The other exception is from Vanuatu to New Caledonia, where more than 81 per cent of the motifs had been shared between these two regions.

If one hypothesises that communities with a stronger connection will employ a higher number of the same motifs, either through local production or exchange, then by performing a Jaccard similarity measure based on the presence of a given motif among these countries, the degree of motif similarity may be identified. Four levels of similarity were generated in accordance with the Jaccard similarity measurements. The range covering 0.0701 to 0.1 represents the highest level of similarity, followed by a secondary high similarity ranging from 0.0401 to 0.07 . The moderate level of similarity ranges from 0.0301 to 0.04 , and the lowest ranging from 0.03 to 0 . Figure 15.1 shows that the highest level of similarity is shared by a line of linking regions, starting from the north-west Solomon Islands Chain, to the Reefs-Santa Cruz Islands, and then to Vanuatu, Fiji and Tonga. The second highest level of similarity appears between the Bismarck Archipelago to the Reefs-Santa Cruz Islands and to New Caledonia, between the Reefs-Santa Cruz Islands to Fiji, and to New Caledonia. It also occurs between the north-west Solomon Islands Chain to Vanuatu, to Fiji and to Tonga, and lastly between Vanuatu and Tonga. The moderate level of 
similarity occurs between the Bismarck Archipelago to Vanuatu and to Fiji, between the ReefsSanta Cruz Islands to Fiji, between New Caledonia to Vanuatu and to Fiji, and lastly between Fiji to Tonga. The lowest level of similarity occurs between the Bismarcks to the north-west Solomon Islands Chain, to Tonga and to Samoa. It also occurs between the north-west Solomon Islands Chain and New Caledonia, between New Caledonia to Tonga and to Samoa, and also between Samoa to Fiji and to Tonga.

In sum, geographical distance between two regions does not seem to be a determinate factor in terms of what motif inventory they shared with each other, especially in the case between the Bismarcks to the north-west Solomon Islands Chain. Whether this may reflect temporal differences among pottery assemblages needs to be investigated further in the future.

If one proposes that potters of the Lapita Cultural Complex knew what was 'good to use' and what was 'not good to use' in the general motif inventory with regards to both local preferences and inherited social status (Chiu 2005, 2007, 2015), then measuring both the presence and absence of a given motif may explore a deeper level of similarity among communities. Just as one Lapita group may have applied a particular set of motifs due to local preferences, it may also have rejected some particular sets of motifs based on the same ideology, as indicated by the distribution pattern of some major motif themes in the following section. Therefore, by hypothesising that potters of all regions knew every motif that existed, the decision by a community to use or not use particular motifs at two given sites can be interpreted in the context of the community's attitude towards said shared motifs (e.g. whether the two communities shared a similar attitude towards the motifs or not). This assumption is of course highly unlikely to have happened in the real world as equal opportunity for knowledge sharing is never easy to achieve. However, it provides a chance to investigate whether a significant difference exists between the motif inventories of these regions.

A Phi correlation measure, which takes into account not only the presence of a given motif at any given site but also its absence, has been performed. In Figure 15.2, the range covering 0.21 to 0.3 represents the highest level of similarity, followed by a secondary high similarity ranging from 0.2 to 0 . A third level ranges from 0 to -0.2 , and the lowest ranging from -0.2 to -0.6 . The strongest similarity measure occurs between the Reefs-Santa Cruz Islands and the northwest Solomon Islands Chain. The second level of similarity can be found between the northwest Solomon Islands Chain and almost all other regions except Samoa. It also occurs between the Reefs-Santa Cruz Islands and Vanuatu, Fiji and Tonga. Both Fiji and Tonga share the same second level of similarity to all other regions except New Caledonia and the Bismarcks. The third level of similarity is from the Bismarcks to the Reefs-Santa Cruz Islands, Vanuatu, Fiji and Tonga. It also occurs between New Caledonia to the Reefs-Santa Cruz Islands, Vanuatu, Fiji and Tonga. The same pattern can be seen between Samoa to the Solomon Islands Chain, the ReefsSanta Cruz Islands and Vanuatu. The lowest similarity measured by Phi is between the Bismarcks and New Caledonia. Therefore, it is clear that, although the Bismarck Archipelago and New Caledonia shared a large number of the same motifs, as indicated by the Jaccard measurement, the motif inventories of these two countries are actually quite different from one another, and also from all other regions.

Both Jaccard and Phi similarity measurements indicate that the Reefs-Santa Cruz Islands shared the highest level of motif similarity with the north-west Solomon Islands Chain. The links among the north-west Solomon Islands Chain, the Reefs-Santa Cruz Islands, Vanuatu, Fiji and Tonga are strong in both measurements. The Bismarcks and New Caledonia seem to be rather different, as they do not always share the same level of motif similarity as their nearest neighbours; however, this result may again demonstrate that current tests are still heavily influenced by sample size issues. 


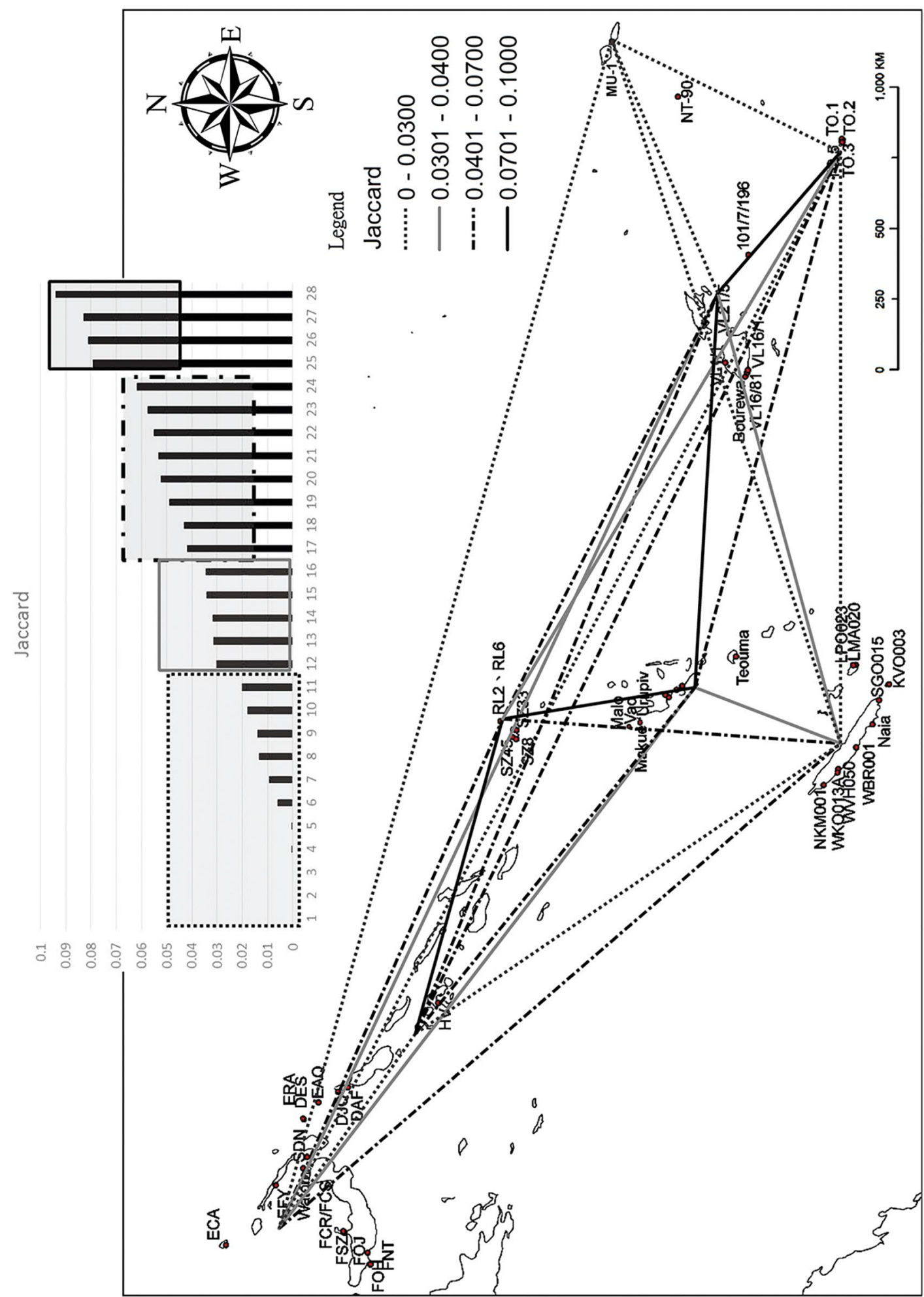

Figure 15.1. Jaccard similarity measure of shared motifs among regions.

Source: Author's summary. 


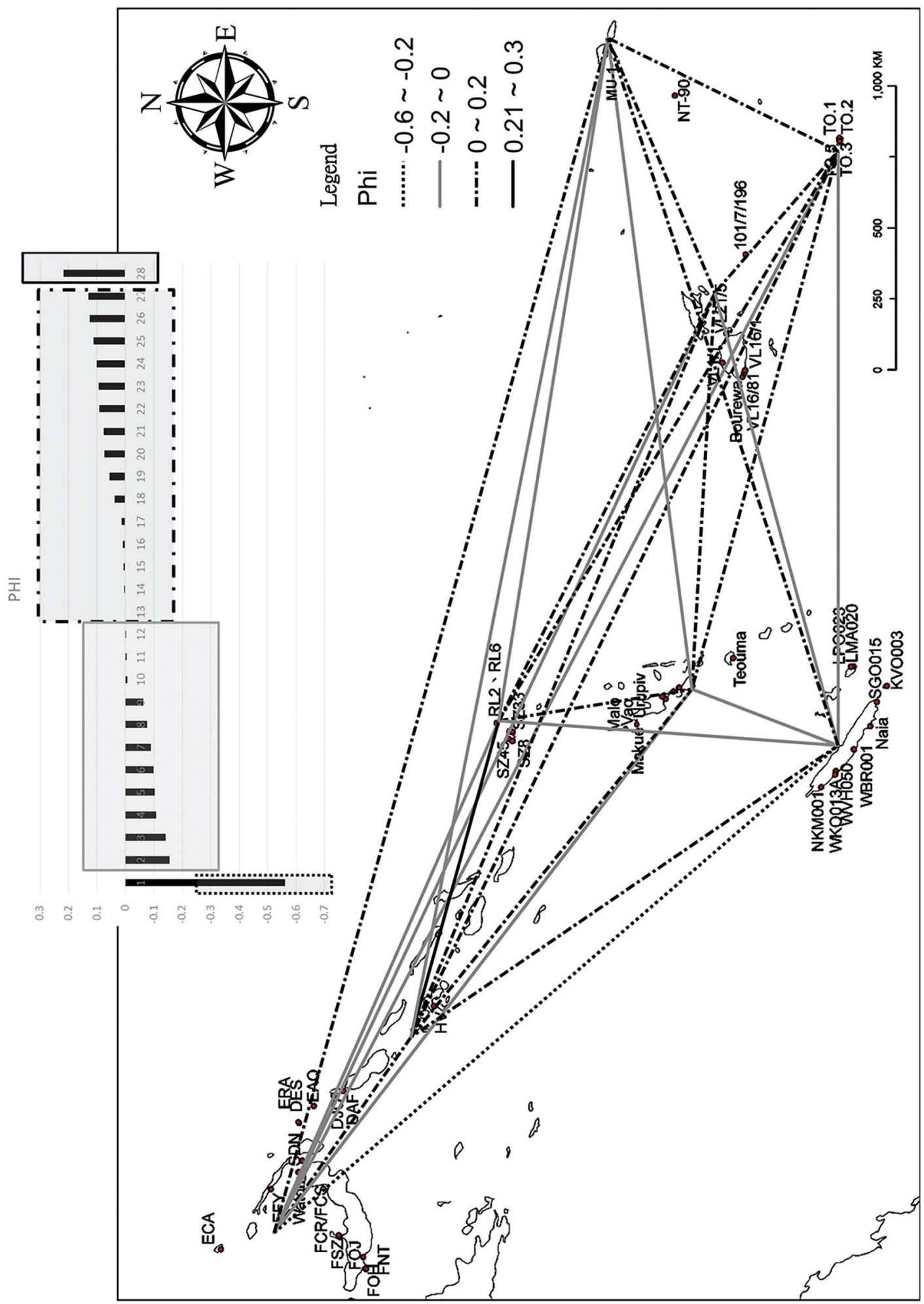

Figure 15.2. Phi correlation measure of shared motifs among regions. Source: Author's summary. 
In the following section, tables containing distribution patterns of different motif themes are summarised (see Tables 15.4-15.13). Most of these motif themes are established based on previously proposed central motif bands (Chiu and Sand 2005; Sand 1996), where alloforms of a general motif image are classified according to the arrangement of design elements into subcategories. Some tables contain updated information from a previous paper (Chiu 2015: Tables 4-7), while the remainder are presented here for the first time. It should be borne in mind that the number representing motif occurrence in a given cell of these tables represents one occurrence of such a motif from a single site within a given region, not a summary of how many times one particular motif appears at any given site. For example, in Table 15.4 the face motif theme contains six subcategories, and a total of 263 individual motifs that occur 277 times among the 50 sites studied.

Some motif themes, such as the face motifs, are rather widespread throughout the Lapita Cultural Complex, with most subcategories showing up at multiple regions except the northwest Solomon Islands Chain (see Table 15.4). Some geometric motif themes, such as the house (see Table 15.5), joined triangle (see Table 15.6) and tongue (see Table 15.7) motif themes, are more frequently modified and shared by numerous regions, while some of their subcategories show a rather limited distribution in certain geographical regions. The zigzag (see Table 15.8) and mushroom and bone (see Table 15.9) motif themes illustrate a rather restricted use for most of their subcategories outside of the Bismarck Archipelago. The undulated motif theme (see Table 15.10) only flourished in New Caledonia, and never reached the Fiji-Tonga-Samoa region. The curvature band motif theme (see Table 15.11), which also did not reach the FijiTonga-Samoa region, seems to have two regional developments, one centred in the Bismarck Archipelago, and the other one employed by potters of the Reefs-Santa Cruz, Vanuatu and New Caledonia. Regarding the highly elaborated labyrinth motif theme (see Table 15.12), only four out of the 14 subcategories are shared by two or more regions, while the remaining 10 subcategories were used only by one single island group. Finally, regarding the spearhead motif theme (see Table 15.13), some of the subcategories were apparently developed once the potters migrated into the Fiji-Tonga-Samoa region and were subsequently not shared with anyone living further west, while another cluster of subcategories was developed either in the Bismarck Archipelago or the Reefs-Santa Cruz Islands. Further examination of the links of individual sites employing these motif themes will no doubt improve our understanding of the social links among these sites, especially in comparison to the selective use of just a portion of the general motif inventory.

In general, within these 10 selected motif themes, the Bismarck Archipelago has all of them, while two of them (the undulated and the curvature band) have yet to be reported from the Fiji-Tonga-Samoa region. Some subcategories were executed by potters located at multiple sites across multiple regions, while some categories seem to have been restricted for use only by potters of one particular site or region. Judging from the distribution pattern of the house and the tongue motif themes, one may expect to find more of these motif themes particularly from sites in Vanuatu once more data from that region become available. 
Table 15.4. Distribution of the face motif theme.

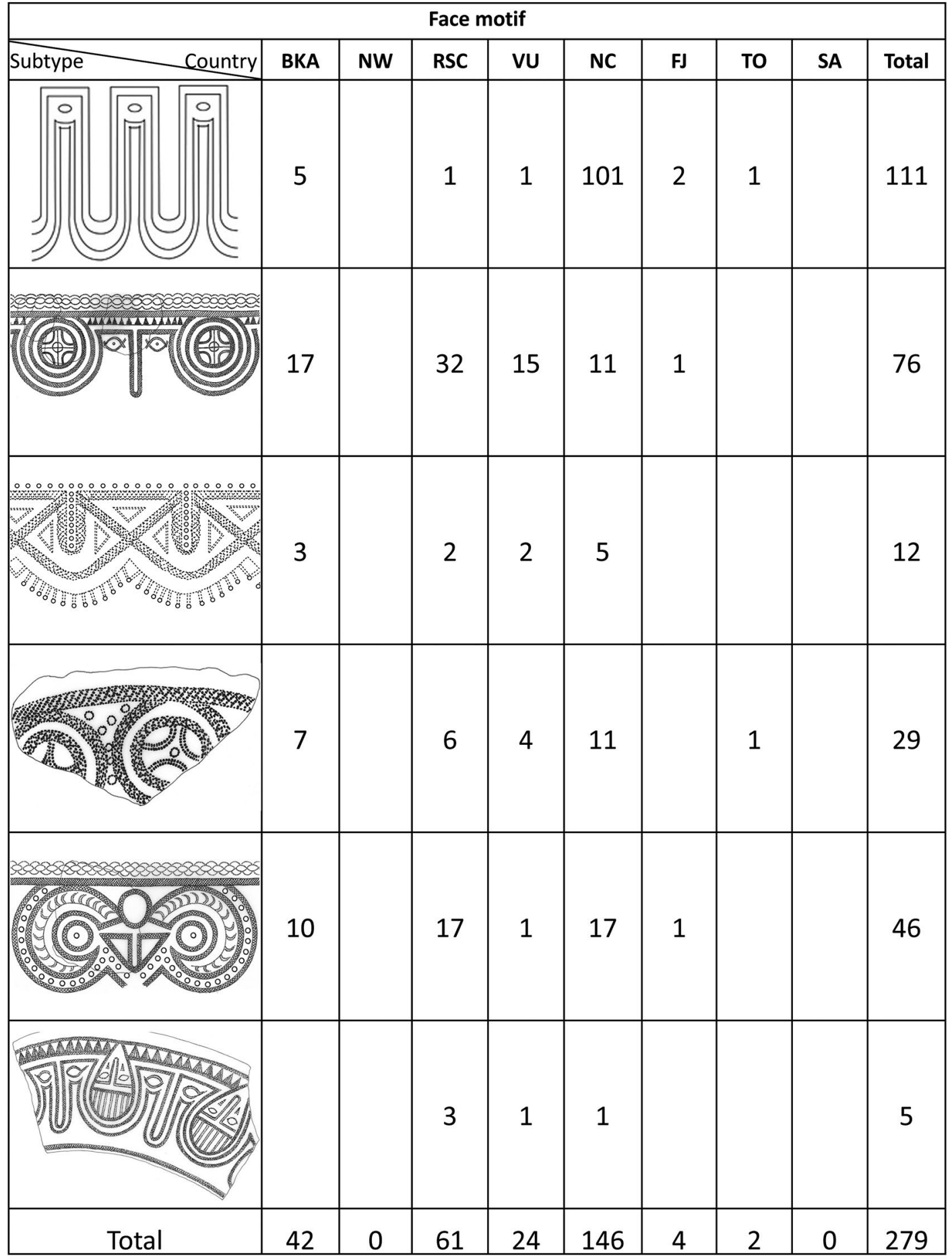

Source: Author's summary. 
Table 15.5. Distribution of the house motif theme.

\begin{tabular}{|l|l|l|l|l|l|l|l|l|}
\hline Subtype & & & & & \\
\hline
\end{tabular}

Source: Author's summary. 
Table 15.6. Distribution of the joined triangles motif theme.

\begin{tabular}{|l|l|l|l|l|l|l|l|l|l|}
\hline \multicolumn{7}{|c|}{ Joined triangles } & \\
\hline Subtype & & & & & & & \\
\hline
\end{tabular}

Source: Author's summary. 
Table 15.7. Distribution of the tongue motif theme.

\begin{tabular}{|c|c|c|c|c|c|c|c|c|c|}
\hline \multicolumn{10}{|c|}{ Tongue } \\
\hline Subtype Country & BKA & NW & RSC & Vu & NC & FJ & TO & SA & Total \\
\hline & 28 & 2 & 12 & 6 & 35 & 4 & 4 & & 91 \\
\hline & 25 & & 5 & 4 & 3 & 6 & 1 & & 44 \\
\hline 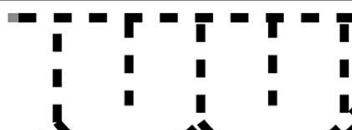 & 27 & & 10 & 7 & 19 & 18 & & & 81 \\
\hline & 3 & & 2 & 1 & 6 & 1 & & & 13 \\
\hline & 9 & & 4 & & 8 & 5 & 1 & & 27 \\
\hline & 11 & & 5 & & 13 & & & & 29 \\
\hline & 1 & & 2 & & & & & & 3 \\
\hline & 4 & & & 1 & 1 & & & & 6 \\
\hline & 20 & & & & 2 & & & & 22 \\
\hline & 8 & & & & 3 & & & & 11 \\
\hline
\end{tabular}

Source: Author's summary. 
Table 15.8. Distribution of the zigzag motif theme.

\begin{tabular}{|c|c|c|c|c|c|c|c|c|c|}
\hline \multicolumn{10}{|c|}{ Zigzag } \\
\hline Subtype Country & BKA & NW & RSC & vu & NC & FJ & TO & SA & Total \\
\hline$\geqslant \geqslant \geqslant \geqslant \geqslant \geqslant \geqslant \geqslant \geqslant \geqslant \geqslant$ & 46 & 1 & 8 & 5 & 5 & 6 & 1 & & 71 \\
\hline & 11 & & 1 & & & & & & 12 \\
\hline & 13 & & & 1 & 1 & & & & 15 \\
\hline & 21 & & & & 1 & & & & 22 \\
\hline & 22 & & & & & & & & 22 \\
\hline & 18 & & & & & & & & 18 \\
\hline & 10 & & & & & & & & 10 \\
\hline & 3 & & & & & & & & 3 \\
\hline Total & 144 & 1 & 9 & 6 & 7 & 6 & 1 & 0 & 173 \\
\hline
\end{tabular}

Source: Author's summary. 
Table 15.9. Distribution of the mushroom and bone motif theme.

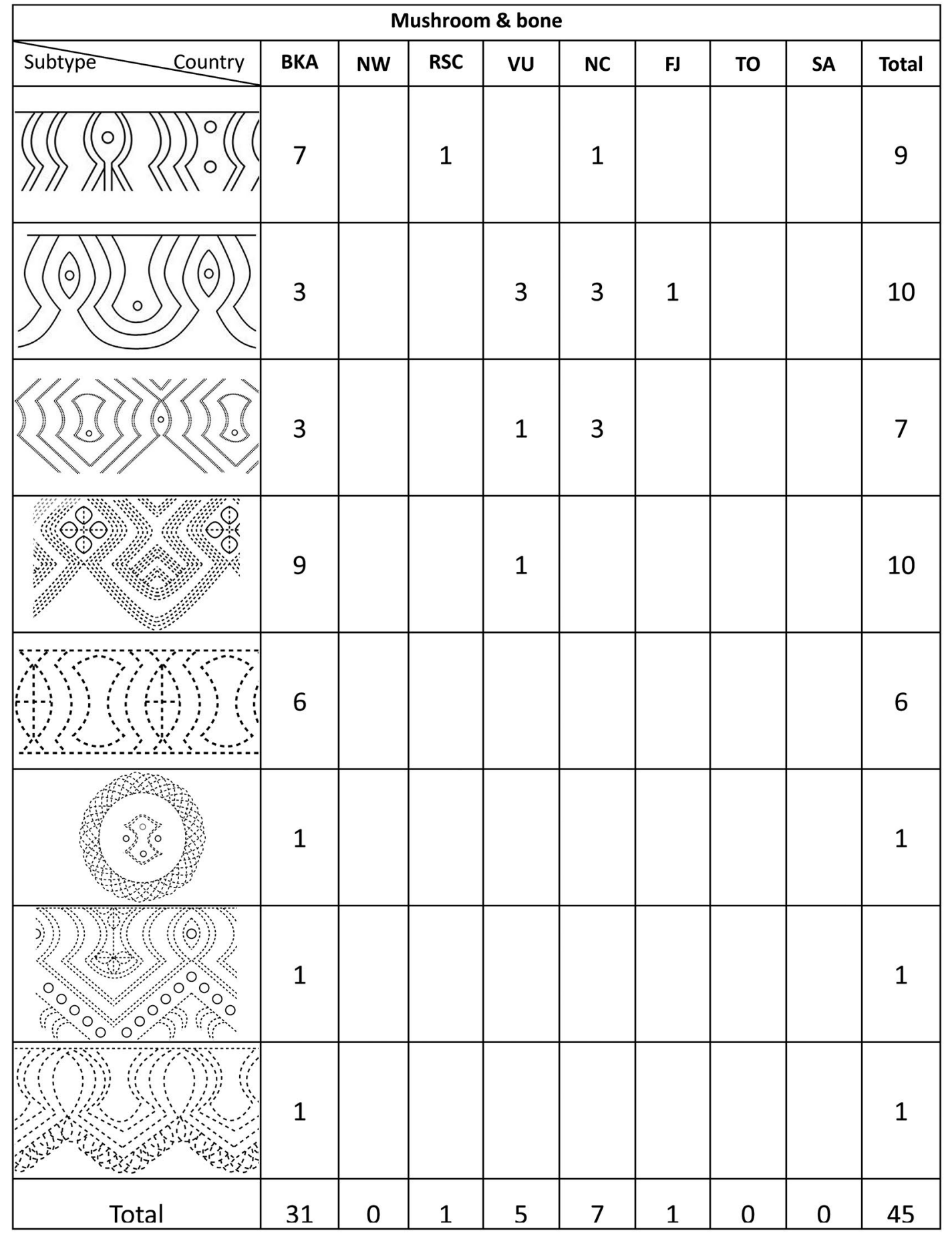

Source: Author's summary. 
Table 15.10. Distribution of the undulated motif theme.

\begin{tabular}{|l|l|l|l|l|l|l|l|l|l|}
\hline \multicolumn{2}{|c|}{ Undulated } & & & & \\
\hline Subtype & BKA & NW & RSC & VU & NC & FJ & TO & SA & Total \\
\hline & & & 12 & 6 & 7 & & & & 26 \\
\hline & 1 & & & & 1 & & & & 2 \\
\hline
\end{tabular}

Source: Author's summary. 
Table 15.11. Distribution of the curvature motif theme.

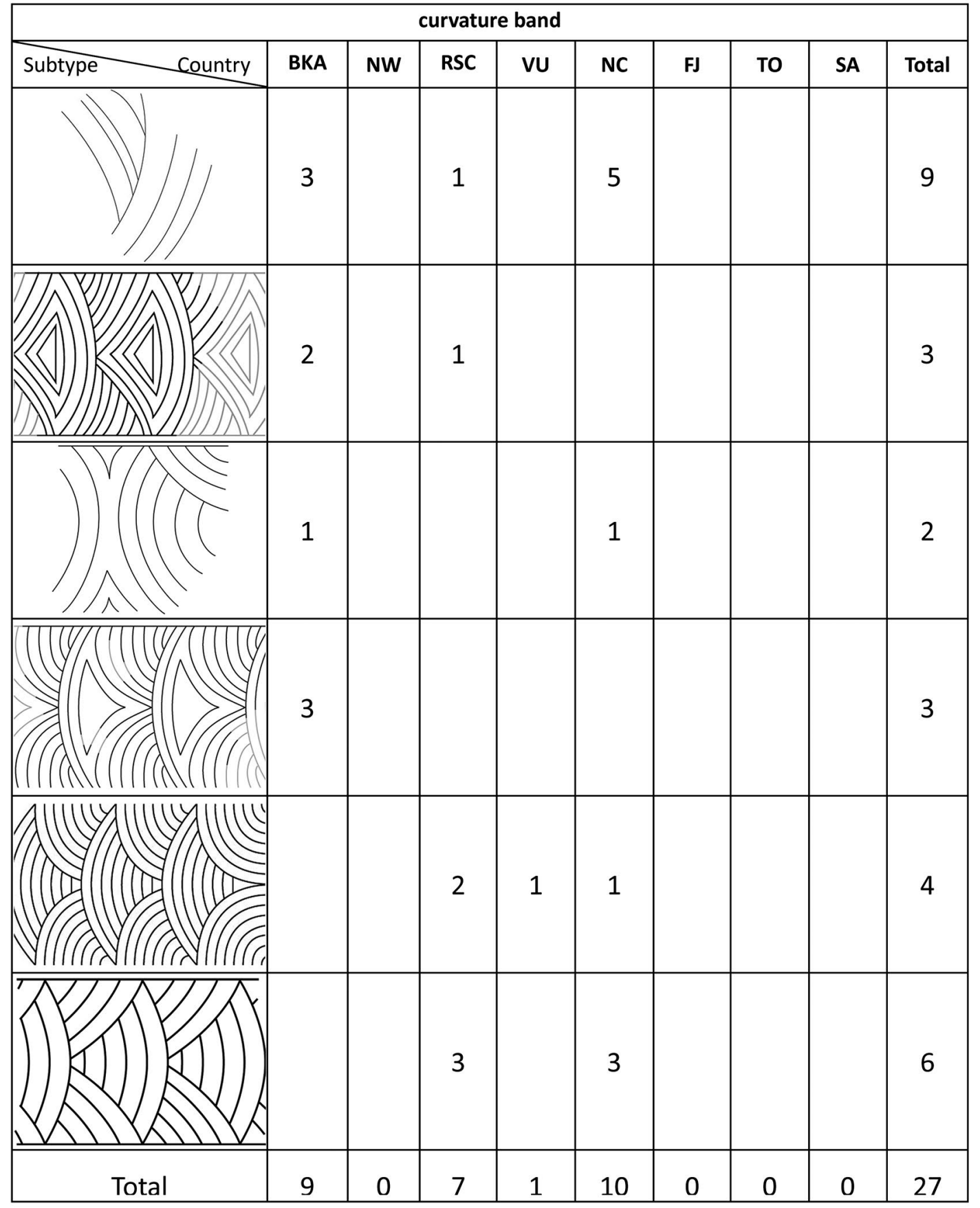

Source: Author's summary. 
Table 15.12. Distribution of the labyrinth motif theme.

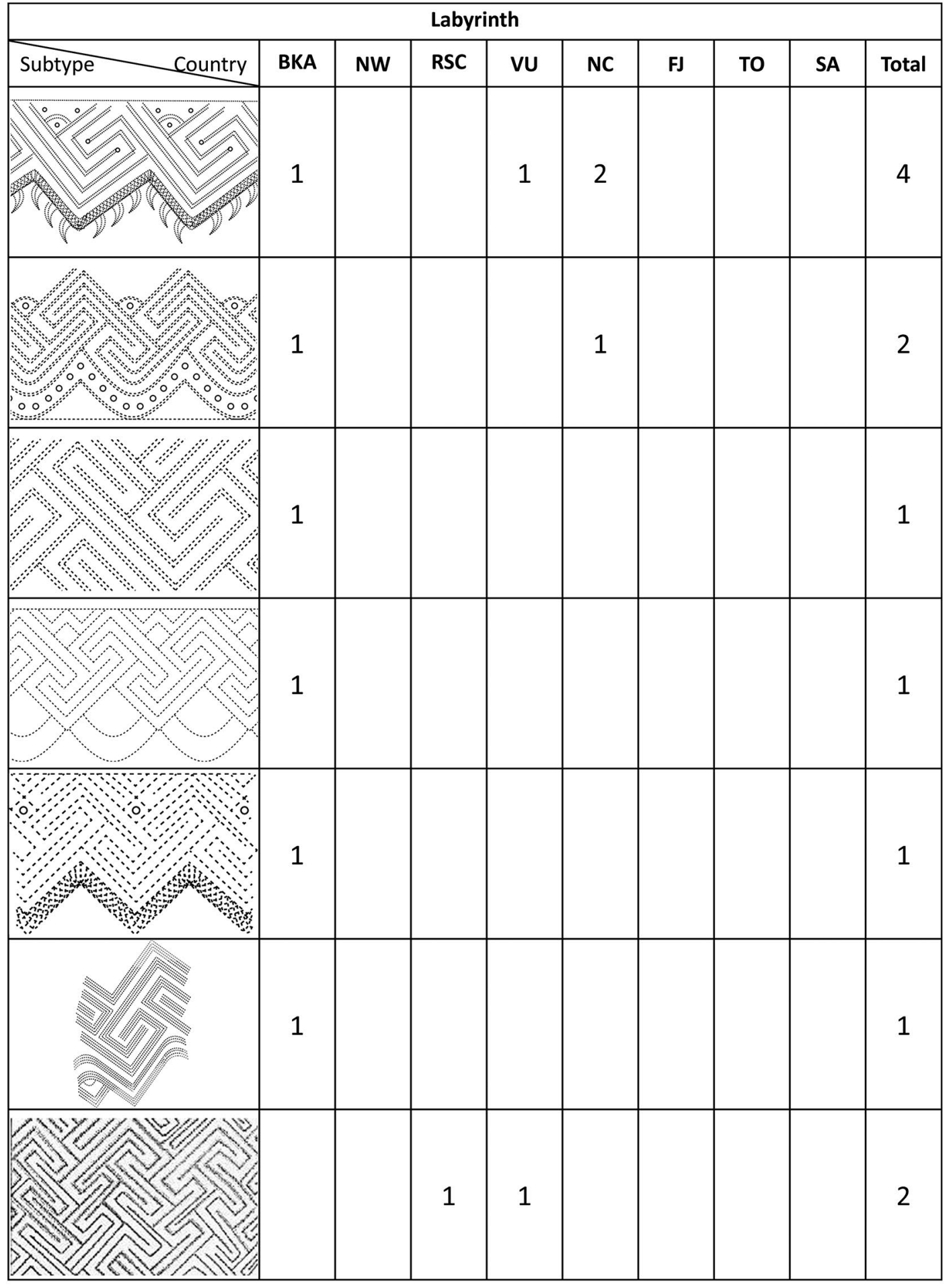




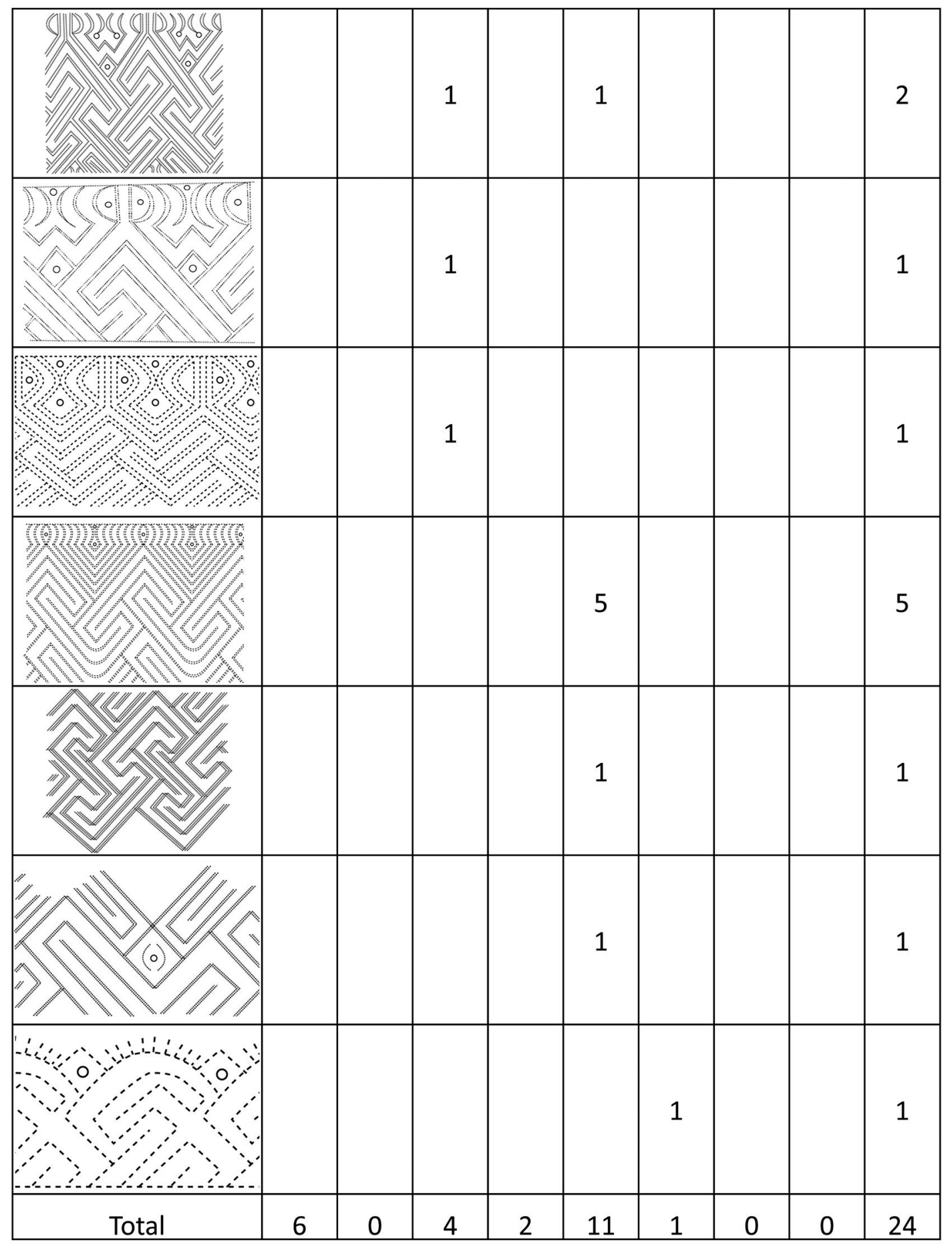

Source: Author's summary. 
Table 15.13. Distribution of the spearhead motif theme.

\begin{tabular}{|c|c|c|c|c|c|c|c|c|}
\hline \multicolumn{9}{|c|}{ Spearheads } \\
\hline Subtype Country & PNG & SI & VU & NC & FJ & TO & SA & Total \\
\hline & 3 & 6 & 4 & 3 & & & & 16 \\
\hline & 4 & 2 & 1 & & & & & 7 \\
\hline & 1 & 2 & & 3 & & & & 6 \\
\hline & 2 & 3 & & & 1 & & & 6 \\
\hline & 1 & 1 & & & & & & 2 \\
\hline & & 1 & & & & & & 1 \\
\hline & & 1 & & & & & & 1 \\
\hline & & & & & 1 & 1 & 1 & 3 \\
\hline & & & & & 3 & 1 & & 4 \\
\hline Total & 11 & 16 & 5 & 6 & 5 & 2 & 1 & 46 \\
\hline
\end{tabular}

Source: Author's summary. 


\section{Discussion}

In this chapter, links among regions have been plotted out using individual motif presence/ absence data and have summarised the distribution patterns of 10 major motif themes identified so far. The motif summary table shows that in most cases, roughly 50-60 per cent of motifs found are unique to a particular region, and also that only a few such motifs have been shared among multiple regions. This indicates that while potters of all these different places kept using similar motifs, they were also capable of creating new motifs, or modifying existing ones, and additionally had the ability to restrict the distribution of particular motifs to a limited geographical range. No matter if one leaves the north-west Solomon Islands Chain assemblages out of the discussion, there seems to be a rather sharp decline of shared motifs between the Reefs-Santa Cruz Islands and Vanuatu, as only 36 per cent of the motifs employed by potters of both the Bismarck Archipelago and the Reefs-Santa Cruz Islands show up in Vanuatu. New Caledonian potters shared more than 80 per cent of these rather 'traditional' motifs with potters of Vanuatu, indicating a strong relationship among these communities. Fijian potters shared about 45 per cent of these traditional motifs with their Vanuatu counterparts, and only 45 per cent of these traditional motifs then passed on to Tonga.

One can hypothesise that communities sharing a high degree of internal similarity with regards to cultural preferences pertaining to motifs will pass on that preference from generation to generation as they migrated out of their homeland (Green and Kirch 1997), and that frequent visits between daughter communities and homeland areas would have facilitated the use of newly innovated motifs among these related communities. If this is so, then the pattern identified via the use of the Jaccard similarity measure indicates that the Reefs-Santa Cruz Islands should be viewed as an important central point in the motif-sharing network. Potters here shared a higher degree of similarity with all regions except Tonga and Samoa. Vanuatu, on the other hand, shares a higher degree of similarity with the north-west Solomon Islands Chain, the Reefs-Santa Cruz Islands, Fiji and Tonga, indicating a relatively later motif-sharing network across the entire Lapita region. Yet the reasons why the motif similarity measure between Vanuatu and New Caledonia is so low, when petrographic analysis has shown multiple instances of pottery transfer from New Caledonia to various Vanuatu Lapita sites (Chiu et al. 2016), are currently unknown. The Phi similarity measurement basically agrees with the pattern identified through Jaccard measurement, while indicating the difference between the Reefs-Santa Cruz Islands and New Caledonia assemblages.

Judging from the number of shared motif subcategories, it is quite clear that not all motif themes are distributed the same way across regions. Data presented in Tables 15.4-15.13 also support the hypothesis that some local modified versions of a well-known motif theme are more likely to be shared only by communities of the same island group, or only among nearby regions. Some, like the undulated and the zigzag motif themes, have quite a restricted distribution, while others, such as the face and the house motif themes, are widespread. Further examination of these motif themes shows that in most cases the majority of motifs within a given subcategory of motif theme are alloforms instead of a direct copy of an existing motif. This indicates that modification instead of truthful reproduction of a given complex motif is the main concern when Lapita potters made their choices. Creation of new motifs also must have been encouraged, as nearly 50 per cent of the motifs in each region recorded so far are unique to that region.

As argued previously, the distribution pattern of these central band motif themes indicates that there was a strong intention to be different from one's immediate neighbour, while at the same time displaying affiliation to more distant groups, by keeping the same underlying motif structure (Chiu 2015:198). Now with more data generated from other motif themes, this tendency is once again confirmed. It is proposed here that localised social identities were constructed in a systematic way across the Lapita range over time, by modifying existing motifs to generate

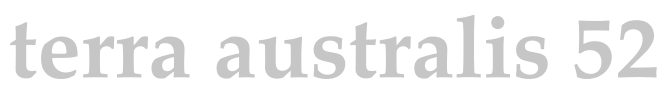


site- or island-specific symbols, while keeping the underlying motif resemblance. To achieve such patterned variation, potters must have known how a 'traditional motif' was constructed, how others had previously modified it, and also had to have sufficient skill to execute a new one that was slightly different from all of the other alloforms. Therefore, this pattern indicates that the regionalisation of motifs and vessel forms and the associated development of stylistic differences over time that are observed in the archaeological record may not have been the result of isolation but may instead have developed through rather intense and continuous interactions. It has been suggested that the process of boundary-making has to be developed through intergroup negotiation, competition and even collaboration (e.g. Chiu 2005; Fennell 2007; Stark 1998). At this stage, without detailed chronological data for all motifs identified so far, it is rather hard to conduct a seriation test to see which subcategory of the face motif theme, for example, was developed first in each of the regions, let alone detailing how it may have evolved through time and space.

The Triple-I model, proposed by Roger Green (Green 1991, 2000, 2003), highlighting the importance of the three processes of intrusion, integration and innovation, has had a tremendous impact on current thinking about the Pacific's past. The Bismarck Archipelago is seen as the geographical location where multiple waves of migration to and from Island Southeast Asia occurred, representing a frontline where the local non-Austronesian-speaking populations had to form new social relationships with immigrants, be they hostile or not (see Kirch 1997; Spriggs 1997 for detailed discussions). A method of communication that was capable of transmitting a message across various languages and cultural traditions was no doubt needed during the initial contact period, the dates of which have varied from place to place. It has been proposed previously that Lapita pottery should be understood as 'symbols at work' (Chiu 2007:257); such symbols, expressed as easily manipulated pottery decorations that can be based on existing symbols, were one of the more powerful tools in their repertoire for getting the message across. These symbols might have aided their attempts to build relationships with incoming individuals or with small groups from different cultural backgrounds.

As new social relationships developed among individuals and small groups, the need to modify old symbols and to create new ones representing their own shared group identities became more and more important. By expressing their shared experience, either through systematically generating patterned differences in existing symbols to link themselves back to the homeland communities, or through articulating new symbols that declare their rights to land and house titles, members of these newly formed social groups can be further integrated with one another (Chiu 2005). It is demonstrated in the above tables that alloforms of a particular motif theme can be further classified into subcategories. Each of these subcategories is recognised based on a similar set of modification rules applied to the original motif structure. Furthermore, particular sets of modification rules can only be found in certain regions. I therefore suggest that alloforms of a motif theme are 'patterned' differences, not just randomly changed. Therefore, Lapita pottery with decorative motifs should be perceived as a practical and innovative means that people of heterogeneous backgrounds employed to manipulate and negotiate their social identities according to the situations they faced. This may be particularly relevant to small group migrations, where building and maintaining multiple sets of overlapping social networks may be highly valued (Keesing 1968:82-83). Just as a person is involved in multiple social networks of various kinds, which may be traced and illustrated by investigating the underlying logic of how they have linked with each other, I propose that important symbols, such as the central band motif themes illustrated here, should also be examined in terms of their patterns of association with other motifs, if one desires to understand their meanings. 
These examples illustrate how particular symbols, the selected 10 motif themes expressed on pottery decoration, might have been used for communication and for the construction of social relationships. The approach outlined here provides a method to examine the ways in which the Lapita communities might have transformed themselves through the use of symbols in time, and the physical manufacture of Lapita pottery. At this stage the issue of sample size, and the ways of classifying alloforms into different motif themes, may prevent us from reaching a clear understanding of the meanings of these motifs. However, by further examining the grammar employed to govern what motifs can be arranged on a certain pottery surface, and thereby gaining an insight into the motif association rules employed, we will no doubt in the future greatly improve our knowledge about these particular aspects of the rules of motif construction of the Lapita potters.

\section{Acknowledgements}

Special thanks go to scholars who have generously granted me access to their pottery assemblages: the late Professor Roger Green, Dr Jim Specht, Professor Glenn R. Summerhayes, Professor Patrick Kirch, Dr Christophe Sand, Dr Jean-Christophe Galipaud, Professor Matthew Spriggs and Dr Stuart Bedford. Many thanks to the wonderful team of research assistants and students who have worked on this project with me over the years, especially Miss Yu-Ying Su and Mr Nicholas Hogg. LPOD has received support from the Research Center for Humanities and Social Sciences, Institute of History and Philology, and the Project for Promoting Digital Archives to Improve Academic Research Environments of Academia Sinica for the past 10 years. Data recorded in this paper were supported in part by MOST-103-2420-H-001-008 to Dr Chiu's research project.

\section{References}

Anson, D. 1983. Lapita pottery of the Bismarck Archipelago and its affinities. Unpublished PhD thesis, University of Sydney, Sydney.

Anson, D. 2000. Reber-Rakival dentate-stamped motifs: Documentation and comparative implications. New Zealand Journal of Archaeology 20:119-135.

Bedford, S. 2006. The Pacific's earliest painted pottery: An added layer of intrigue to the Lapita debate and beyond. Antiquity 80:544-557. doi.org/10.1017/S0003598X00094023.

Bedford, S. and J.-C. Galipaud 2010. Chain of islands: Lapita in the north of Vanuatu. In C. Sand and S. Bedford (eds), Lapita: Ancêtres Océaniens/Oceanic ancestors, pp. 122-137. Musée du quai Branly and Somogy, Paris.

Bedford, S. and M. Spriggs 2007. Birds on the rim: A unique Lapita carinated vessel in its wider context. Archaeology in Oceania 42(1):12-21. doi.org/10.1002/j.1834-4453.2007.tb00010.x.

Bedford, S., M. Spriggs, R. Regenvanu, C. Macgregor, T. Kuautonga and M. Sietz 2007. The excavation, conservation and reconstruction of Lapita burial pots from the Teouma Site, Efate, Central Vanuatu. In S. Bedford, C. Sand and S.P. Connaughton (eds), Oceanic explorations: Lapita and Western Pacific settlement, pp. 223-240. Terra Australis 26. ANU E Press, Canberra. doi.org/10.22459/TA26.2007.

Bedford, S., M. Spriggs, H. Buckley, F. Valentin, R. Regenvanu and M. Abong 2010. A cemetery of first settlement: The site of Teouma, South Efate, Vanuatu. In C. Sand and S. Bedford (eds), Lapita: Ancêtres Océaniens/Oceanic ancestors, pp. 140-161. Musée du quai Branly and Somogy, Paris. 
Best, S. 1984. Lakeba: The prehistory of a Fijian island. Unpublished PhD thesis, University of Auckland, Auckland.

Birks, L. 1973. Archaeological excavations at Sigatoka Dune Site, Fiji. Bulletin of the Fiji Museum No. 1. Fiji Museum, Suva.

Burley, D.V. and S.P. Connaughton 2010. Completing the story: A Late Lapita dentate stamped pot from Sigatoka, Fiji. Archaeology in Oceania 45:130-132. doi.org/10.1002/j.1834-4453.2010.tb00090.x.

Chiu, S. 2003. The socio-economic functions of Lapita ceramic production and exchange: A case study from Site WKO013A, Koné, New Caledonia. Unpublished PhD thesis, University of California, Berkeley.

Chiu, S. 2005. Meanings of a Lapita face: Materialized social memory in ancient house societies. Taiwan Journal of Anthropology 3(1):1-47.

Chiu, S. 2007. Detailed analysis of Lapita face motifs: Case studies from Reef-Santa Cruz Lapita sites and New Caledonia Lapita Site 13A. In S. Bedford, C. Sand and S.P. Connaughton (eds), Oceanic explorations: Lapita and Western Pacific settlement, pp. 241-264. Terra Australis 26. ANU E Press, Canberra. doi.org/10.22459/TA26.2007.

Chiu, S. 2015. Where do we go from here? Social relatedness reflected by motif analysis. In C. Sand, S. Chiu and N. Hogg (eds), The Lapita Cultural Complex in time and space: Expansion routes, chronologies and typologies, pp. 185-206. Archeologia Pasifika 4. Institut d'archéologie de la NouvelleCalédonie et du Pacifique (IANCP), Nouméa.

Chiu, S. and C. Sand 2005. Recording of the Lapita motifs: Proposal for a complete recording method. Archaeology in New Zealand 48(2):133-150.

Chiu, S., D. Killick, C. Sand and W.R. Dickinson 2016. Connection and competition: Some early insights gained from petrographic studies of New Caledonian Lapita pottery. Archaeology in Oceania 51(2): 141-149. doi.org/10.1002/arco.5093.

Clark, G. 2010. The remote horizon: Lapita dispersal in Fiji-West Polynesia. In C. Sand and S. Bedford (eds), Lapita: Ancêtres Océaniens/Oceanic ancestors, pp. 212-223. Musée du quai Branly and Somogy, Paris.

Doherty, M. 2009. Post-Lapita developments in the Reef-Santa Cruz Islands, Southeast Solomon Islands. In P.J. Sheppard, T. Thomas and G.R. Summerhayes (eds), Lapita: Ancestors and descendants, pp. 181-213. New Zealand Archaeological Association Monograph 28. New Zealand Archaeological Association, Auckland.

Donovan, L.J. 1973. A study of the decorative system of the Lapita potters in Reefs and Santa Cruz Islands. Unpublished MA thesis, University of Auckland, Auckland.

Fennell, C.C. 2007. Crossroads and cosmologies: Diasporas and ethnogenesis in the New World. University Press of Florida, Gainesville Florida.

Galipaud, J.-C. 2010. Makué and Shokraon: Earliest arrivals and cultural transformations in northern Vanuatu. In C. Sand and S. Bedford (eds), Lapita: Ancêtres Océaniens/Oceanic ancestors, pp. 138-139. Musée du quai Branly and Somogy, Paris.

Gifford, E.W. and D. Shutler Jr 1956. Archaeological excavations in New Caledonia. Anthropological Records 18(1). University of California Press, Berkeley and Los Angeles.

Golson, J. 1961. Report on New Zealand, Western Polynesia, New Caledonia, and Fiji. Asian Perspectives 5:166-180. 
Gorecki, P., J. Head and S. Bassett 1991. A Lapita site at Lamau, New Ireland mainland. In J. Allen and C. Gosden (eds), Report of the Lapita Homeland Project, pp. 217-221. Occasional Papers in Prehistory 20. Department of Prehistory, RSPacS, The Australian National University, Canberra.

Green, R.C. 1976. Lapita sites in the Santa Cruz group. In R.C. Green and M.M. Cresswell (eds), Southeast Solomon Islands cultural history: A preliminary survey, pp. 245-265. Royal Society of New Zealand Bulletin 11. Royal Society of New Zealand, Wellington.

Green, R.C. 1979. Lapita. In J.D. Jennings (ed.), The prehistory of Polynesia, pp. 27-60. Harvard University Press, Cambridge, Mass. doi.org/10.4159/harvard.9780674181267.c3.

Green, R.C. 1991. The Lapita Cultural Complex: Current evidence and proposed models. Bulletin of the Indo-Pacific Prehistory Association 11:295-305. doi.org/10.7152/bippa.v11i0.11393.

Green, R.C. 2000. Lapita and the cultural model for intrusion, integration and innovation. In A.J. Anderson and T. Murray (eds), Australian archaeologist: Collected papers in honour of Jim Allen, pp. 372-392. Coombs Academic Publishing, The Australian National University, Canberra.

Green, R.C. 2003. The Lapita horizon and traditions-Signature for one set of Oceanic migrations. In C. Sand (ed.), Pacific archaeology: Assessments and prospects. Proceedings of the conference for the 50th anniversary of the first Lapita excavation, Kone-Nouméa, 2002, pp. 95-120. Les cahiers de l'archéologie en Nouvelle-Calédonie 15. Département Archéologie, Service des Musées et du Patrimoine de Nouvelle-Calédonie, Nouméa.

Green, R.C. and P.V. Kirch 1997. Lapita exchange systems and their Polynesian transformations: Seeking explanatory models. In M.I. Weisler (ed.), Prehistoric long-distance interaction in Oceania: An interdisciplinary approach, pp. 19-37. New Zealand Archaeological Association Monograph 21. New Zealand Archaeological Association, Auckland.

Hedrick, J.D. n.d. Archaeological investigation of Malo prehistory: Lapita settlement strategy in the northern New Hebrides. Unpublished draft PhD thesis, University of Pennsylvania, Philadelphia, PA.

Kay, R. 1984. Analysis of archaeological material from Naigani. Unpublished MA thesis, University of Auckland, Auckland.

Keesing, R.M. 1968. Nonunilineal descent and contextual definition of status: The Kwaio evidence. American Anthropologist 70:82-84. doi.org/10.1525/aa.1968.70.1.02a00080.

Kirch, P.V. 1988. Niuatoputapu: The prehistory of a Polynesian chiefdom. Thomas Burke Memorial Washington State Museum Monograph 5. Burke Museum, Seattle.

Kirch, P.V. 1997. The Lapita peoples: Ancestors of the Oceanic world. Blackwell, Cambridge.

Kirch, P.V. 2000. On the road of the winds: An archaeological history of the Pacific Islands before European contact. University of California Press, Berkeley and Los Angeles.

Lave, J. and E. Wenger 1991. Situated learning: Legitimate peripheral participation. Cambridge University Press, Cambridge. doi.org/10.1017/CBO9780511815355.

Mead, S.M. 1975. The decorative system of the Lapita potters of Sigatoka, Fiji. In S.M. Mead, L. Birks, H. Birks and E. Shaw (eds), The Lapita pottery style of Fiji and its associations, pp. 19-43. The Polynesian Society Memoir No 38. Polynesian Society, Wellington.

Mead, S.M., L. Birks, H. Birks and E. Shaw 1975. The Lapita pottery style of Fiji and its associations. The Polynesian Society Memoir No. 38. Polynesian Society, Wellington.

Phelan, M. 1997. Scratching the surface: The Lapita pottery of Makekur, Papua New Guinea. BA Hons thesis, Department of Archaeology, La Trobe University, Melbourne. 
Poulsen, J. 1987. Early Tongan prehistory: The Lapita period on Tongatapu and its relationships. Two volumes. Terra Australis 12. Department of Prehistory, RSPacS, The Australian National University, Canberra.

Rossitto, R. 1995. Stylistic change in Fijian Pottery. Pacific Studies 18:1-45.

Sand, C. 1995. 'Le temps d'avant': Préhistoire de la Nouvelle-Calédonie. Harmattan, Paris.

Sand, C. 1996. Le début du peuplement Austronésien de la Nouvelle-Calédonie: Données archéologiques recéntes. Les cahiers de l'archéologie en Nouvelle-Calédonie 6. Département Archéologie, Service des Musées et du Patrimoine de Nouvelle-Calédonie, Nouméa.

Sand, C. 2007a. The Eastern frontier: Lapita ceramics in the Fiji-West Polynesia region. In S. Chiu and C. Sand (eds), From Southeast Asia to the Pacific: Archaeological perspectives on the Austronesian expansion and the Lapita Cultural Complex, pp. 214-242. Centre for Archaeological Studies, Research Centre of Humanities and Social Sciences. Academia Sinica, Taipei.

Sand, C. 2007b. Looking at the big motifs: A typology of the central band decorations of the Lapita ceramic tradition of New Caledonia (Southern Melanesia) and preliminary regional comparisons. In S. Bedford, C. Sand and S.P. Connaughton (eds), Oceanic explorations: Lapita and Western Pacific settlement, pp. 265-287. Terra Australis 26. ANU E Press, Canberra. doi.org/10.22459/TA26.2007.

Sand, C. 2010. The End of era: Established settlement and the cultural diversification of Lapita traditions. In C. Sand and S. Bedford (eds), Lapita: Ancêtres Océaniens/Oceanic ancestors, pp. 270-287. Musée du quai Branly and Somogy, Paris.

Sand, C., J. Bolé and A. Ouétcho 2002. Site LPO023 of Kurin: Characteristics of a Lapita settlement in the Loyalty Islands (New Caledonia). Asian Perspectives 41:129-147. doi.org/10.1353/asi.2002.0010.

Sheppard, P.J. 2011. Lapita colonization across the Near/Remote Oceania boundary. Current Anthropology 52(6):799-840. doi.org/10.1086/662201.

Spriggs, M. 1990. The changing face of Lapita: Transformation of a design. In M. Spriggs (ed.), Lapita design, form and composition: Proceedings of the Lapita Design Workshop, Canberra, December 1988, pp. 83-122. Occasional Papers in Prehistory 19. Department of Prehistory, RSPacS, The Australian National University, Canberra.

Spriggs, M. 1997. The Island Melanesians. Blackwell, Oxford.

Stark, M.T. 1998. The archaeology of social boundaries. Smithsonian Institution Press, Washington, DC.

Summerhayes, G.R. 2000. Lapita interaction. Terra Australis 15. Department of Archaeology and Natural History and the Centre for Archaeological Research, The Australian National University, Canberra.

Weiner, A.B. 1992. Inalienable possessions: The paradox of keeping-while-giving. University of California Press, Berkeley. doi.org/10.1525/california/9780520076037.001.0001.

Wickler, S. 2001. The prehistory of Buka: A stepping stone island in the Northern Solomons. Terra Australis 16. Department of Archaeology and Natural History and Centre for Archaeological Research, The Australian National University, Canberra. 
This text is taken from Debating Lapita: Distribution, Chronology, Society and Subsistence, edited by Stuart Bedford and Matthew Spriggs, published 2019 by ANU Press,

The Australian National University, Canberra, Australia.

doi.org/10.22459/TA52.2019.15 